\title{
高血圧自然発症ラットの前立腺上皮細胞の形態的異常
}

\author{
中村ハルミ 杉本次郎 小島 隆 児玉和茂 武知雅人 \\ 三菱化成株式会社安全性研究所 \\ 板倉智敏 北海道大学獸医学部比較病理学教室
}

\section{MORPHOLOGICAL ABNORMALITY OF THE EPITHELIUM IN THE PROSTATE GLAND OF SPONTANEOUSLY HYPERTENSIVE RATS}

\author{
Harumi Nakamura, Jiro Sugimoto, Takashi Kojima, Kazushige Kodama, and Masato Takechi \\ Safety Research Laboratory, Mitsubishi Kasei Co., Ltd
}

Chitoshi Itakura Department of Comparative Pathology, Faculty of Veterinary Medicine, Hokkaido University

\begin{abstract}
Histopathological and electron microscopical studies were made on epithelial cells of the prostate gland in spontaneously hypertensive rats (SHR) and compared with those of Wistar-Kyoto rats (WKY).

The prostate gland tissue of SHR showed a developmental retardation at 5 weeks of age. At and after 18 weeks of age (terminal experimental age was 31 weeks), and glands were small in size with tall columnar epithelial cells, frequently protruding into the glandular lumens and scant secretory substance. On the other hand, the prostate of WKY had large-sized glands with small columnar or cuboidal epithelial cells and with abundant secretory substance.

Electron-microscopically, the cytoplasm of glandular epithelial cells of SHR had well-developed rough endoplasmic reticulum (RER), but Golgi apparatus was small in size and undeveloped. In addition, there were fewer condensed vacuoles and secretory granules.

From these findings, it was considered that transfer of secretory materials from RER to Golgi apparatus was congenitally disturbed and the secretory cycle was inhibited in the epithelium of the prostate gland of SHR. (J Toxicol Pathol 4: 183 193, 1991)
\end{abstract}

Key words : Spontaneously hypertensive rats, Prostate, Secretory disorder, Ultrastructure

\section{緒 言}

高血圧自然発症ラット spontaneously hypertensive rat (SHR)は, 1963 年に京都大学の Okamoto とAoki ${ }^{16}$ により Wistar-Kyoto rat (WKY) から 作出された本態性高血圧症の疾患モデルである。 我々はSHRの前立腺の上皮細胞が他の系統の ラットに比べて丈が高く，腺自身も小型であるこ とを認めた。このような前立腺の形態的異常につ

Accepted for publication: August 22, 1991

Mailing address: Harumi Nakamura, Safety Research Laboratory, Mitsubishi Kasei Co., Ltd., 1000 Kamoshidacho, Midori-ku, Yokohama-shi, Kanagawa 227, Japan.
いての報告は見当たらない。なお，文献的には本 系統の生殖器系の病変として, SHR およびSHR の亜型である脳卒中易発症 SHR (SHRSP) の精細 管を中心とした精巣病変が報告されている。それ によると, その病変は高血圧性血管病変に起因し たものと考えられている7,14,15,18。

本論文では, SHR の前立腺の形態的異常を, WKY と比較しながら記述し，その変化の形態的 発現機序について考察する。

\section{材料および方法}

\section{1. 使用動物}

4 週齢の SHR (星野試験動物) の雄 40 匹を平底 
ケージに 2 匹飼いにし，室温 $20 \sim 25^{\circ} \mathrm{C}$, 湿度 40 $\sim 77 \%, 12$ 時間照明 (午前 7 時〜午後 7 時) の条件 下のコンベンショナル飼育室で飼育した。給与飼 料は MF (オリンタル酵母工業)で，これを水道水 とともに自由に摄取させた。また，対照として同 一条件下で飼育したWKYを用いた。これらの動 物は $5,9,18$ および 31 週䓱時に 10 例ずつ無選択 的に選んで計画殺し, 以下に示す項目について検 索した。

\section{2. 検查項目}

まず，飼育期間中の動物の一般状態および死亡 の有無を休日を除き 1 日 1 回観察した。体重は週 1 回測定した。血圧測定は計画殺の直前に間接法 により実施した。すなわち，ラット自動血圧測定 装置 PS-100 (理研開発) を用い, 尾動脈の最高血 圧を測定した。

計画殺時のラットはギロチンによって断頭さ れ，その際に採取した血清について，テストステ ロンとエストラジオールを三菱油化 BCL 株 に依 頼して測定した。この測定は性成熟する前の 9 週 齢と成熟後の 18 ならびに 31 週齢のSHR および WKYと 5 匹ずつについて行った。

殺後のすべての動物については, 肉眼観察を 行って後前立腺を採材し,これを $10 \%$ 中性緩衝木 ルマリンで固定した。組織標本は通常の方法に従 い, ヘマトキシリン・エオジン (H.E.) 染色標本 を作製した。さらに, 計画殺したSHR および WKY から各々 4 例ずつを選び, 電顕標本を作製

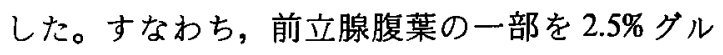
タール固定液, 続いて $1 \%$ 四酸化オスミウム水溶 液で固定し, Queto1812 に包埋し, 超薄切片は酢酸 ウラニル・クエン酸鉛（U-Pb）で重染色した。切 片は透過型電子顕微鏡日立 H-7000 型で観察し た。

な扔, 体重, 捸餌量, 最高血圧, ホルモン測定 值については Yukms 統計ライブラリーI（ユッ クムス)を用いて統計学的処理を行った。

成 績

\section{1. 一般状態}

飼育期間中，全動物に異常はみられなかった。

\section{2. 体重, 摄慨量}

SHR およびWKY の飼育期間中の体重の推移 を Fig. 1 に，捸慨量の推移を Fig. 2 に示す。WKY に比べ SHR の体重は 8 10 週齢を除き, 飼育期 間を通じて有意に低值を示したのに対し，攝餌量 はWKYに比べSHR がほぼ飼育期間を通じて有 意に高值を示した。

\section{3. 血圧}

5 週齢を除く各週齢時における最高血圧の推移 をFig. 3 に示す。 9 週歯のWKY の血圧は平均 $133 \pm 6.1 \mathrm{mmHG}$ であったのに対し，SHRのそれ は平均 $180 \pm 21.5 \mathrm{mmHG}$ と異常な高值を示した。 両系統のラットとも，血圧は週齢を経るにつれて 次第に高くなっていた。すなわち,WKYならびに

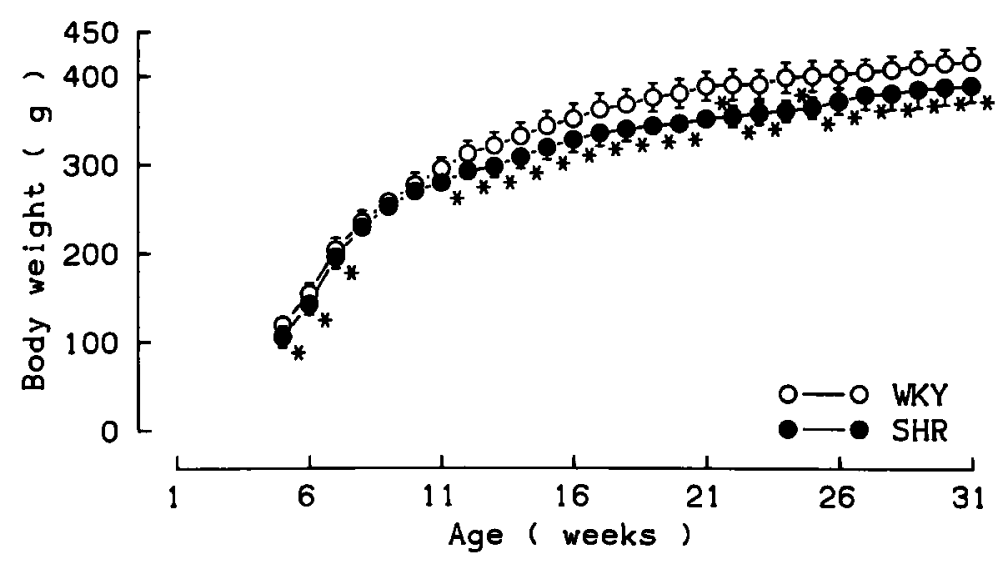

Fig. 1. Body weight (average \pm S.D.) in WKY and SHR groups.

Analysis of significance by Student's $t$ test : ${ }^{*} \mathrm{P}<0.05$ (compared with WKY). 


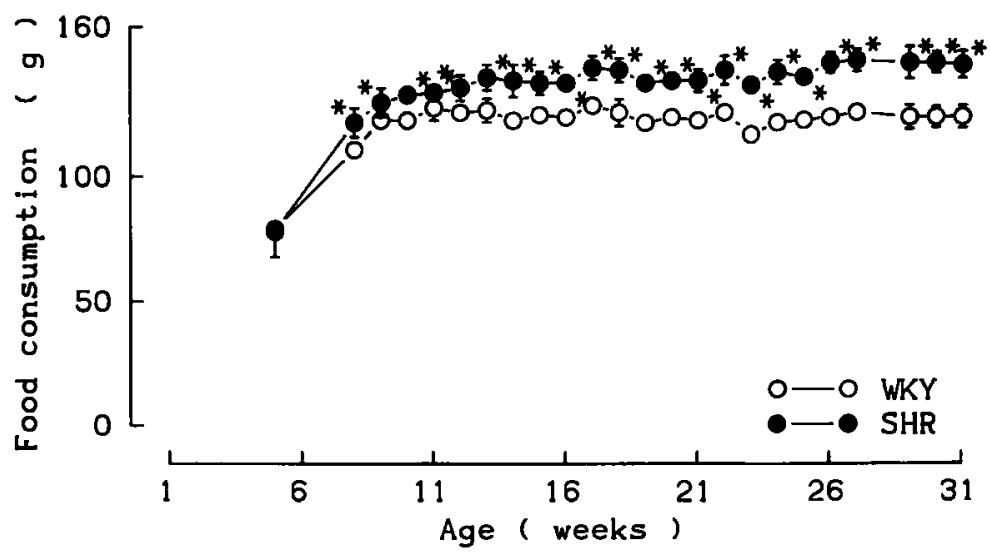

Fig. 2. Food consumption (average \pm S.D.) in WKY and SHR groups.

Analysis of significance by Student's $t$ test : ${ }^{*} \mathbf{P}<0.05$ (compared with WKY)

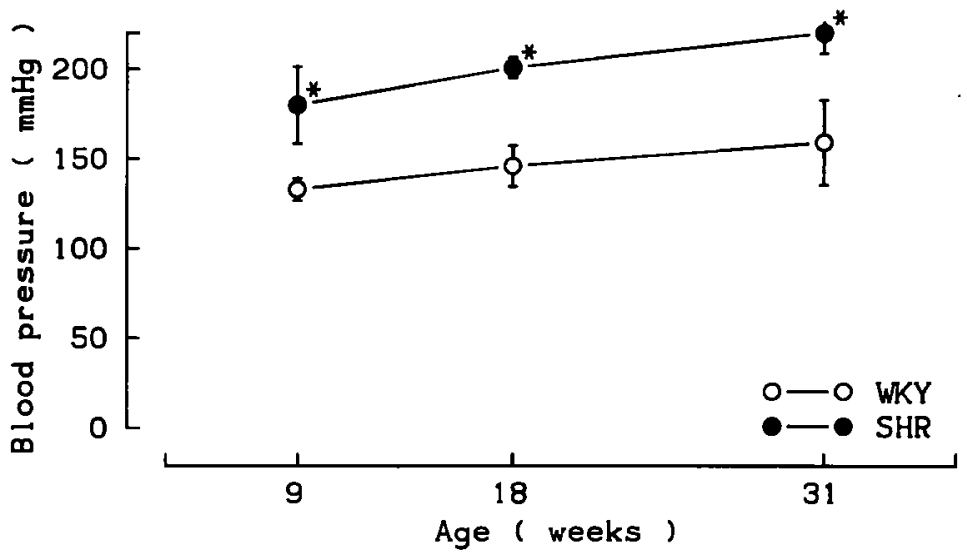

Fig. 3. Blood pressure (average \pm S.D.) in WKY and SHR groups. Analysis of significance by Student's $t$ test : ${ }^{*} \mathbf{P}<0.05$ (compared with WKY).

SHRのそれぞれの平均血圧は，18 週涌で $146 \pm$ $11.6 \mathrm{mmHG}$ ならびに $201 \pm 5.8 \mathrm{mmHG}, 31$ 週齢で

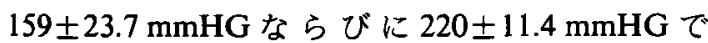

あった。以上のように，いずれの值もWKYに比 べ, SHR が有意に高い值を示した。

Table 1. Testosterone and Estradiol Levels in the Blood Serum

\begin{tabular}{ccccccc}
\hline \multirow{2}{*}{ Age (weeks) } & $\begin{array}{c}\text { No. of rats } \\
\text { examined }^{\mathrm{a})}\end{array}$ & $\begin{array}{c}\text { Testosterone }^{\mathrm{b})} \\
(\mathrm{ng} / \mathrm{ml})\end{array}$ & $\begin{array}{c}\text { Estradiol }^{\mathrm{c})} \\
(\mathrm{pg} / \mathrm{ml})\end{array}$ & & $\begin{array}{c}\text { Sestosterone } \\
(\mathrm{ng} / \mathrm{ml})\end{array}$ & $\begin{array}{c}\text { Estradiol }^{\mathrm{c})} \\
(\mathrm{pg} / \mathrm{ml})\end{array}$ \\
\hline 9 & 5 & $2.3 \pm 1.2$ & $<10-24^{\mathrm{d})}$ & & $2.6 \pm 0.7$ & $<10^{\mathrm{d})}$ \\
18 & 5 & $1.9 \pm 0.8$ & $<10-19^{\mathrm{e})}$ & & $3.9 \pm 2.4$ & $<10-10^{\mathrm{e})}$ \\
31 & 5 & $1.4 \pm 0.8$ & $<10^{\mathrm{e})}$ & & $4.3 \pm 2.8$ & $<10^{\mathrm{e})}$ \\
\hline
\end{tabular}

\footnotetext{
a): Number of rats examined in each WKY and SHR group.

b) : Values are average \pm S.D. No significance by Student' $t$ test (compared with WKY group).

c) Values are minimum-maximum measured in each WKY and SHR group.

b) : Analysis of significance by Wilcoxon test : $P<0.05$ (compared with WKY group)

e) : No significance by Wilcoxon test (compared with WKY group).
} 


\section{4. 血清テストステロンならびにエストラジオール}

5 週歯を除く各計画殺日に採取した血清中のテ ストステロンならびにエストラジオールの測定值 を Table 1 に示す。いずれの週齢においてもSHR のテストステロン值はWKYより高值を示した が，有意差はなかった。また，エストラジオール についても両系統間に有意差は認められなかつ た。

\section{5. 肉眼所見}

SHRの前立腺は，いずれの週齢においても
WKY に比べて小さく，18および 31 週齢時には 前立腺と精䢽を分離する際に, 流出する帯黄色ゼ ラチン状の分泌物の量が WKYより明らかに少 量であった。

\section{6. 臓器重量}

前立腺（腹葉，側葉，背葉を含む）の絶対重量 ならびに相対重量を Table 2 に示す。前立腺の絶 対重量ならびに相対重量は，いずれの週齢におい てもWKYに比べ, SHR が有意に低值を示した。

Table 2. Weight of the Prostate at Necropsy

\begin{tabular}{|c|c|c|c|c|c|}
\hline \multirow{2}{*}{ Age (weeks) } & \multirow{2}{*}{$\begin{array}{l}\text { No. of rats } \\
\text { examined }^{\text {a) }}\end{array}$} & \multicolumn{2}{|c|}{ A.P.W. ${ }^{\mathrm{b})}(\mathrm{g})$} & \multicolumn{2}{|c|}{ R.P.W. ${ }^{c)}(100 \mathrm{~g} / \mathrm{BW})$} \\
\hline & & WKY & SHR & WKY & SHR \\
\hline 5 & 10 & $0.11 \pm 0.02$ & $0.08 \pm 0.01^{*}$ & $0.10 \pm 0.02$ & $0.07 \pm 0.01^{*}$ \\
\hline 9 & 10 & $0.63 \pm 0.06$ & $0.55 \pm 0.06^{*}$ & $0.26 \pm 0.02$ & $0.23 \pm 0.02^{*}$ \\
\hline 18 & 10 & $1.18 \pm 0.09$ & $1.03 \pm 0.07^{*}$ & $0.32 \pm 0.03$ & $0.30 \pm 0.02^{*}$ \\
\hline 31 & 10 & $1.36 \pm 0.12$ & $1.15 \pm 0.08^{*}$ & $0.33 \pm 0.03$ & $0.30 \pm 0.02^{*}$ \\
\hline
\end{tabular}

a) : Number of rats examined in each WKY and SHR group.

b): Values are average \pm S.D. of absolute prostate weight.

Analysis of significance by Student's $t$ test : ${ }^{*} \mathbf{P}<0.05$ (compared with WKY group).

c): Values are average \pm S.D. of relative prostate weight.

Analysis of significance by Student's $t$ test: ${ }^{*} \mathrm{P}<0.05$ (compared with WKY group)

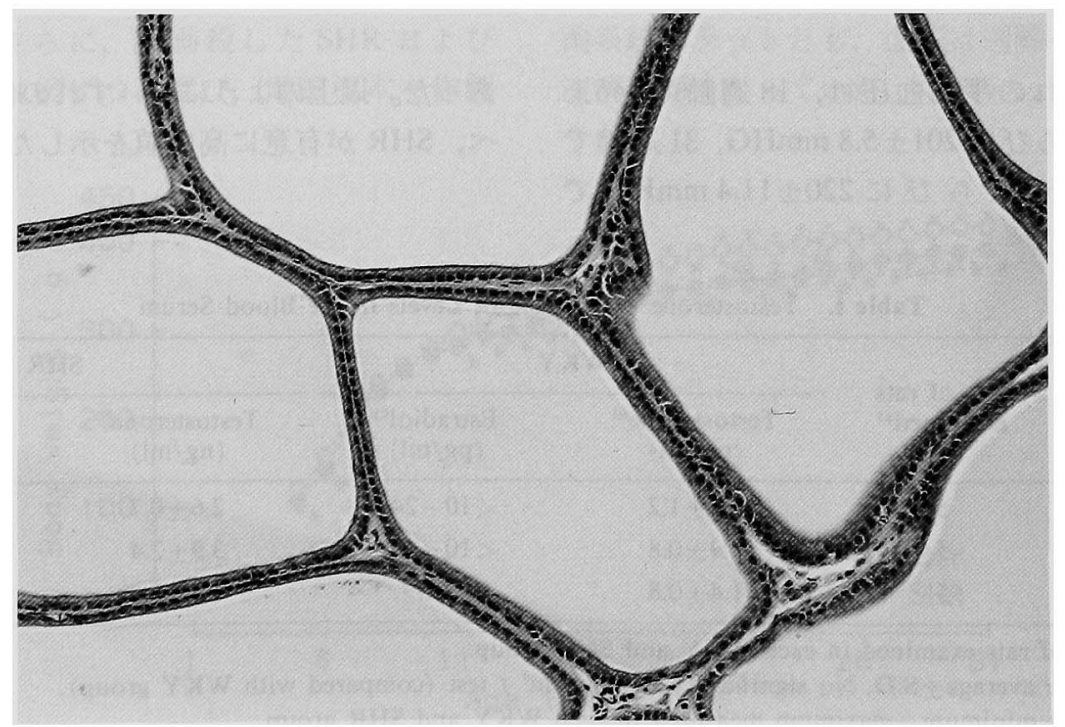

Fig. 4. Prostate of WKY, 18 weeks old.

Glands are lined with dark cuboidal or columnar epithelial cells. H.E., stain. $\times 760$. 


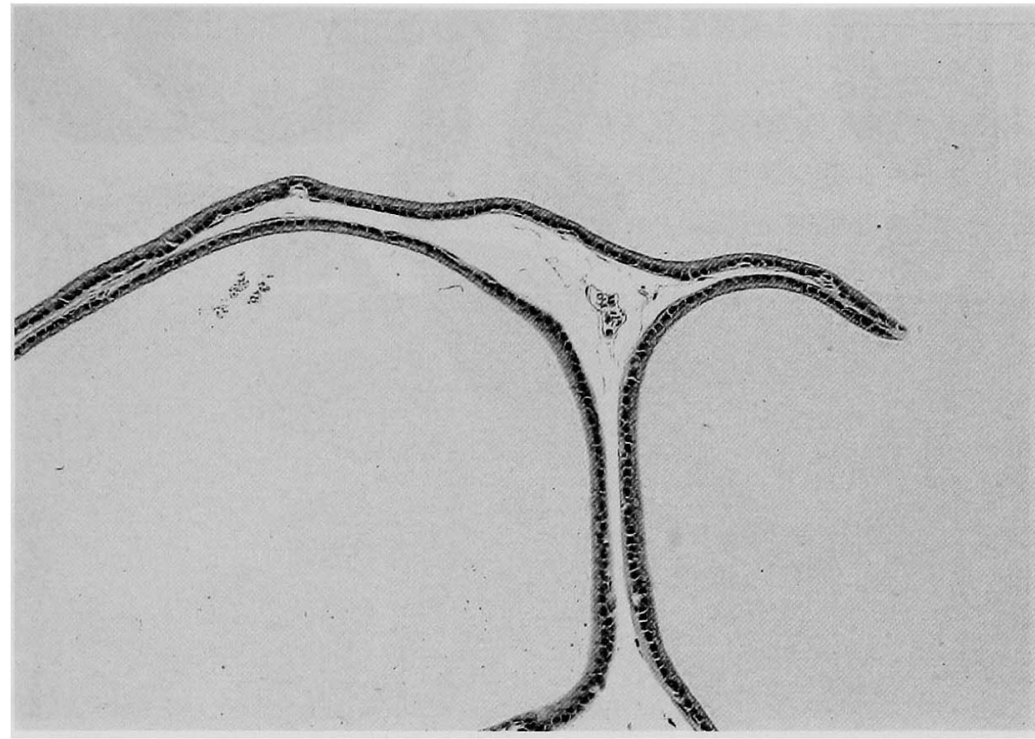

Fig. 5. Prostate of WKY, 31 weeks old.

Glands are larger than those of 18 weeks old, which contained much secretory materials. The epithelial cells are cuboidal. H.E., stain. $\times 760$.

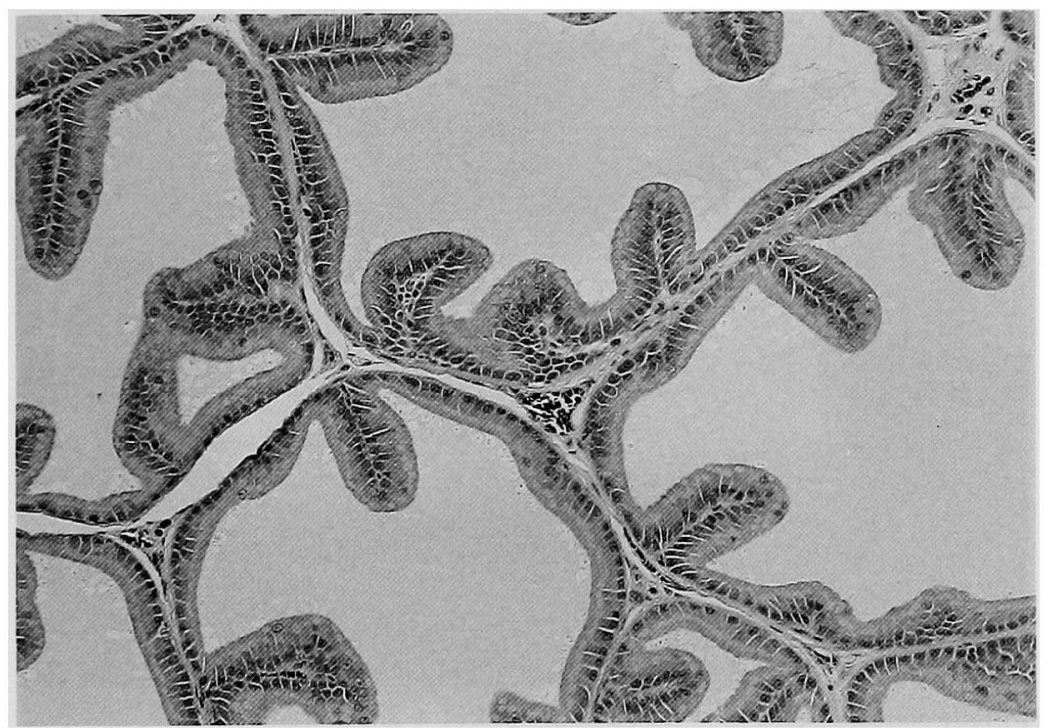

Fig. 6. Prostate of SHR, 18 weeks old.

Glands are narrowed and are lined with tall columnar epithelial cells, frequently showing papillary protrusions. Their cytoplasm is moderately clear with pale area in the free surface side. H.E., stain. $\times 760$.

\section{7. 前立腺腹葉の病理組織学的所見（Figs. 4 7)}

WKY： 5 週紫では前立腺の腺の数は少なく, 全 体的に腺構造は未発達で, 腺腔内の分泌液の量も 少なかった。9週齢では腺組織は発達し, 腺組織の
周囲の結合組織は疎になり，腺腔内には分泌液の 貯留も多くなっていた。性成熟後の 18 週齢になる と腺構造はさらに発達し, 腺腔内の分泌液の量も 増加し, 内張りする上皮細胞の形態は円柱状から 立方状になっていた (Fig. 4)。31 週齢では腺腔内 


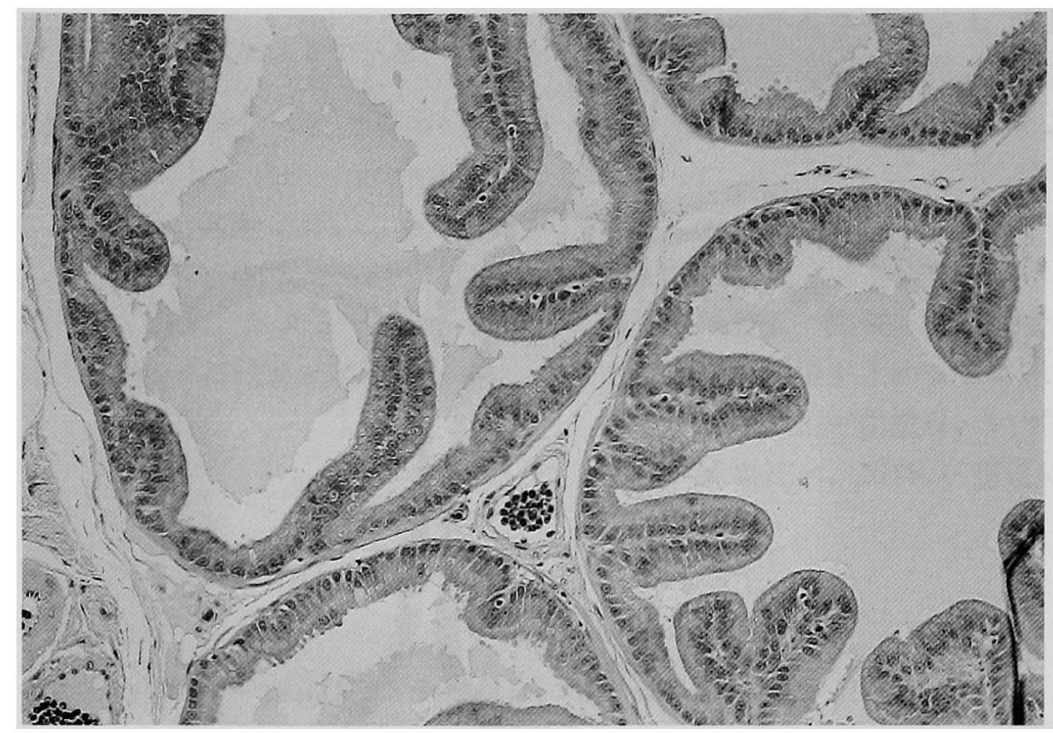

Fig. 7. Prostate of SHR, 31 weeks old.

Almost the same structures as that in rats 18 weeks old (Fig. 3). H.E., stain. $\times 760$.

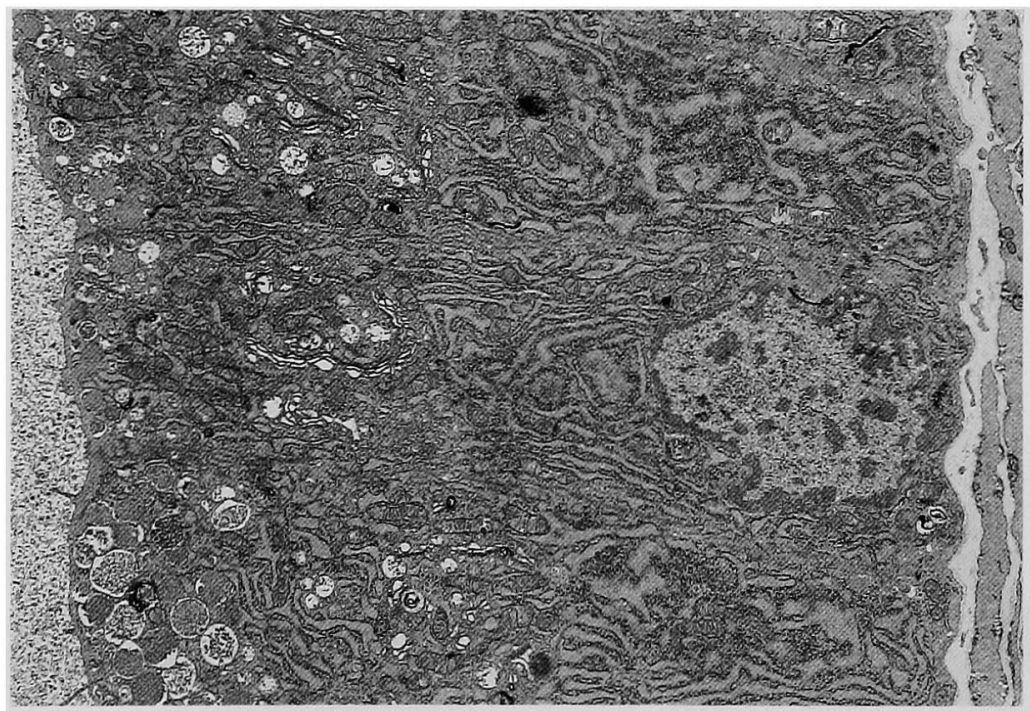

Fig. 8. Prostatic epithelial cells in WKY, 5 weeks old.

Well-developed rough endoplasmic reticulum and Golgi apparatus are observed. There are electron dense secretory granules in the cytoplasm near the free surface.

$\mathrm{U}-\mathrm{Pb}$ stain. $\times 5,500$.

に分泌液が充満し，上皮細胞は丈の低い立方状な いしは扁平状であった（Fig. 5)。

SHR : 5. 週齢では腺の多くは未熟な上皮細胞で 内張りされ, 腺腔はスリット状で未発達な腺で構 成され，WKYに比較して腺構造の発達が遅延し
ていた。9週齢においても全体的に腺は未だ発達 不十分で, 腺腔は狭く, 分泌液の貯留もほとんど みられなかった。 18 週歯林よび 31 週齢において も,WKYに比較して腺腔は明らかに狭く, 腔を内 張りする上皮細胞は丈の高い円柱状で，上皮はし 
ばしば乳頭状に腺腔内に突出していた（Figs.6, 7)。

\section{8. 前立腺腹葉上皮細胞の超微形態学的所見 (Figs. 8 $\sim 15)$}

WKY： 5 週齢の上皮細胞では, 細胞底部に存在 する核の上層部に良く発達した粗面小胞体ならび にゴルジ装置が観察された。粗面小胞体は軽度に

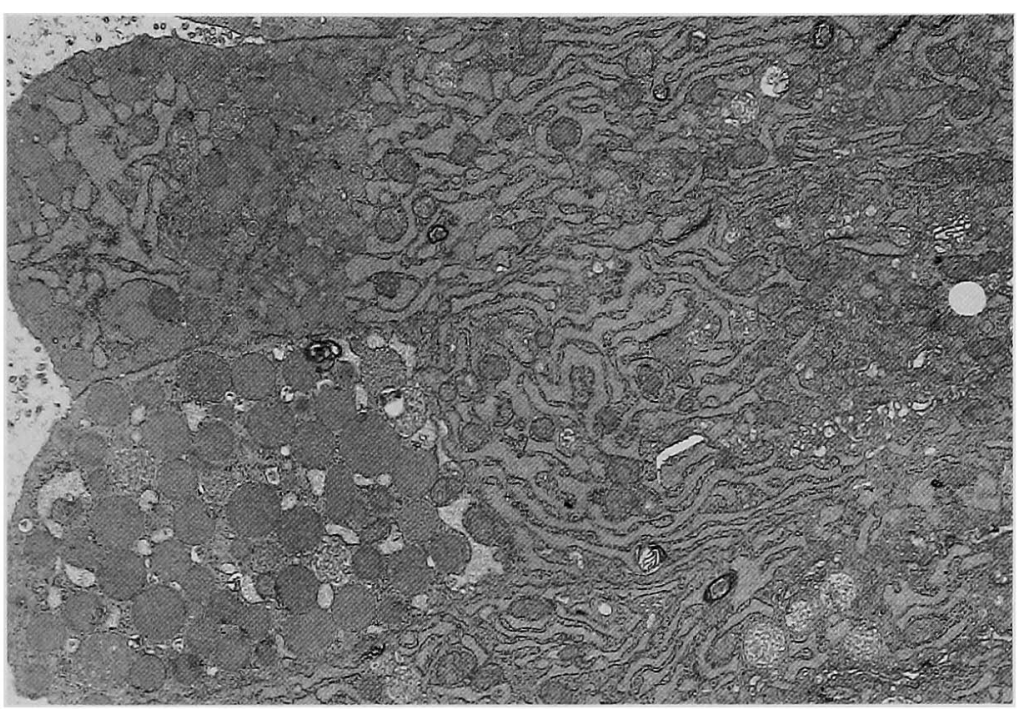

Fig. 9. Prostatic epithelial cells in WKY, 9 weeks old.

Well-developed rough endoplasmic reticulum and Golgi apparatus are observed. The former is frequently dilated. There are many electron dense secretory granules in the cytoplasm beneath the free surface. $\mathrm{U}-\mathrm{Pb}$ stain. $\times 7,000$.

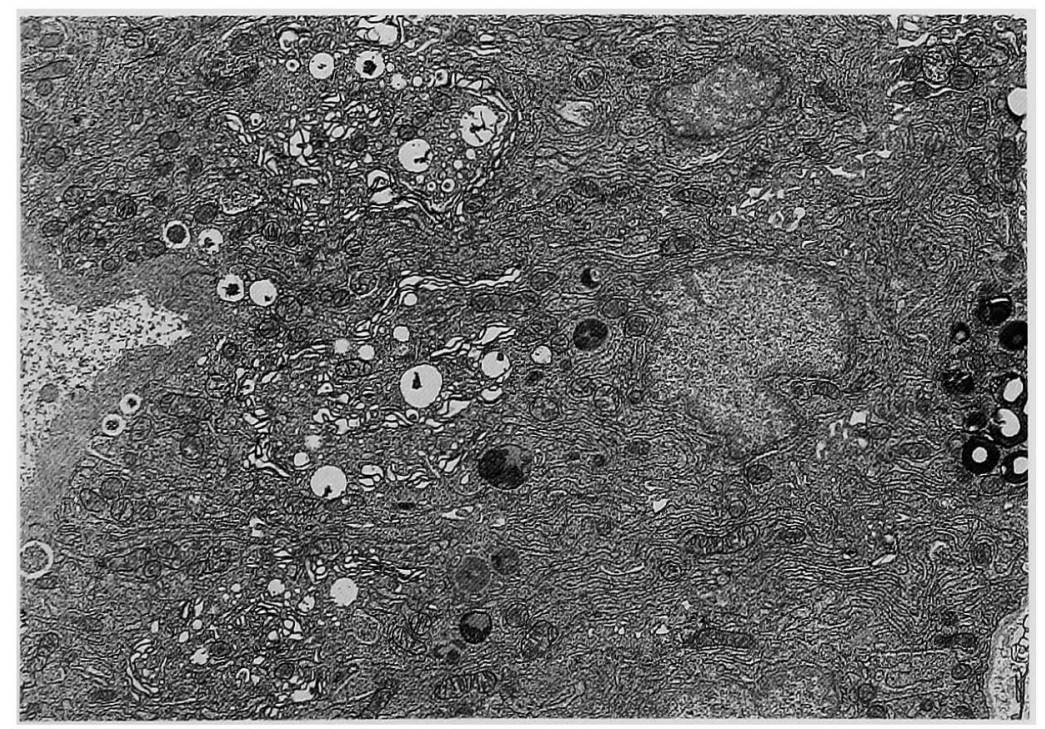

Fig. 10. Prostatic epithelial cells in WKY, 18 weeks old.

The sacs of rough endoplasmic reticulum are collapsed, but Golgi apparatus is markedly activated (enlarged) with Golgi vacuoles of various sizes.

$\mathrm{U}-\mathrm{Pb}$ stain. $\times 5,500$. 
搪張し，その内腔には電子密度が中等度のほほ均 一な物質を入れていた。ゴルジ装置の腺腔側には， 1 層の限界膜に囲まれた大小の濃縮空胞が観察さ れた。これらの濃縮空胞は粗粒子状で，オスミウ ムに中等度好性の物質を入れていた。細胞質の腺
腔に近い部分には, 高電子密度の分泌顆粒が多く みられた(Fig. 8)。9 週齢では 5 週齢に比べて細胞 の丈が高くなり，粗面小胞体が細胞質全域に密に 良く発達し,ゴルジ装置もさらに発達していた。ま た, 分泌顆粒も増加していた (Fig. 9)。18 週齢で

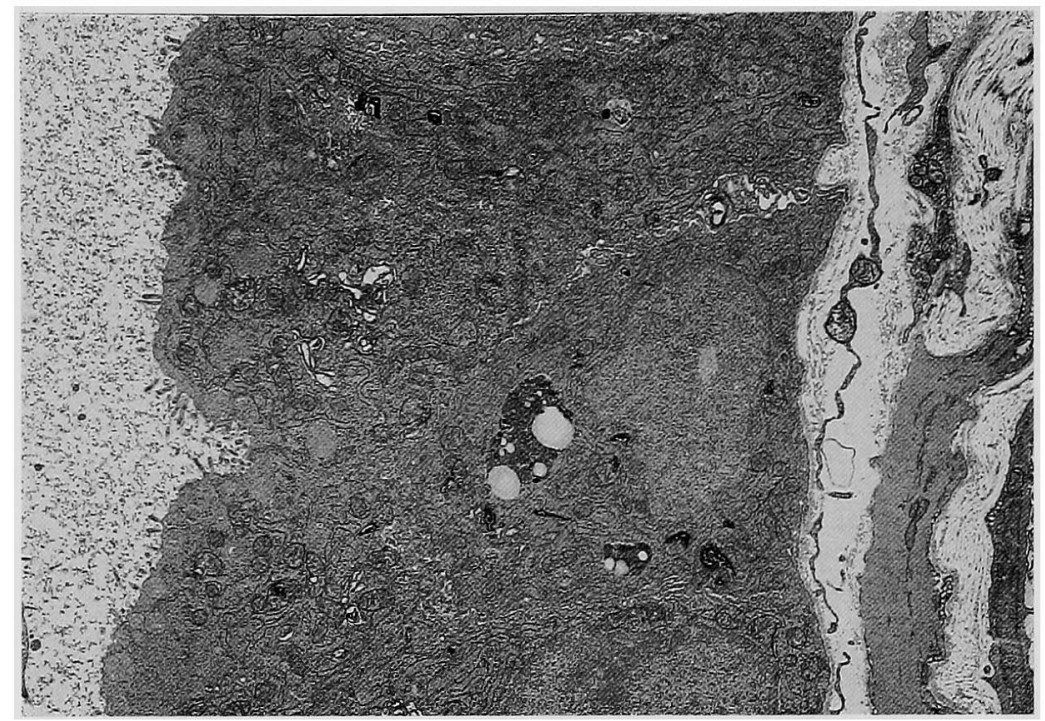

Fig. 11. Prostatic epithelial cells in WKY, 31 weeks old.

Rough endoplasmic reticulum is decreased in number and Golgi apparatus is small in size. Secretory granules are fewer.

$\mathrm{U}-\mathrm{Pb}$ stain. $\times 6,300$.

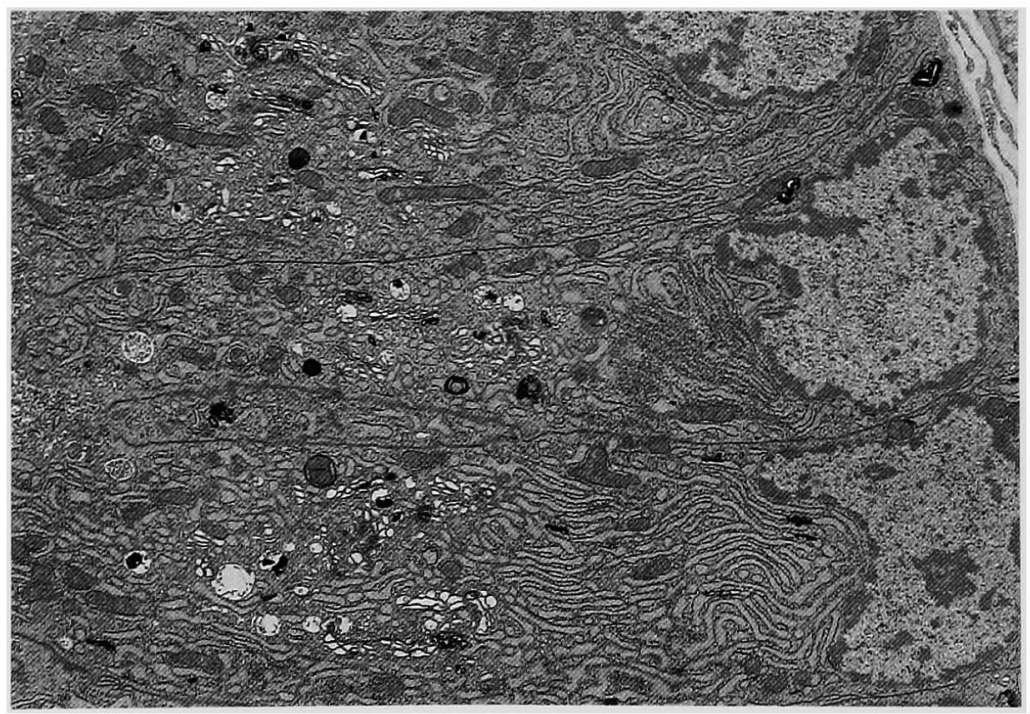

Fig. 12. Prostatic epithelial cells in SHR, 5 weeks old.

Rough endoplasmic reticulum is comparatively developed, but Golgi apparatus is small in size. Some condenced vacuoles and granules are present in the Golgi area.

$\mathrm{U}-\mathrm{Pb}$ stain. $\times 5,500$. 
は 9 週齢に比べ，細胞の丈が低くなり，粗面小胞 体は減少していたが，その腔は抁張していた。し かし，Fig. 10 のように粗面小胞体腔が拡張せず, ゴルジ装置が著しく活性化している細胞もあっ た。31 週齢では 18 週齢時より粗面小胞体は減少
し，ゴルジ装置は小さく，分泌顆粒が減少してい た (Fig. 11)。

SHR : 5 週齢では WKY に比較してゴルジ装置 は小型で, 濃縮空胞ならびに分泌顆粒の数, 大き さともに小さかった (Fig. 12)。9 週齢では上皮細

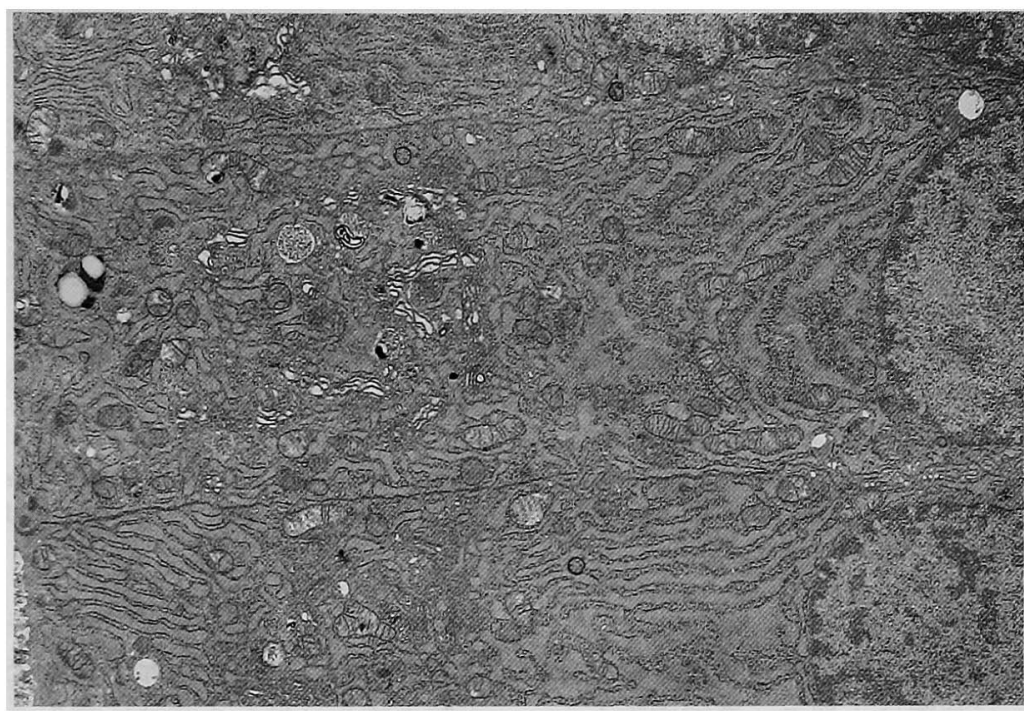

Fig. 13. Prostatic epithelial cells in SHR, 9 weeks old.

Rough endoplasmic reticulum is relatively well-developed, but Golgi apparatus is small in size. Condensed vacuoles and granules are fewer. $\mathrm{U}-\mathrm{Pb}$ stain. $\times 7,000$.

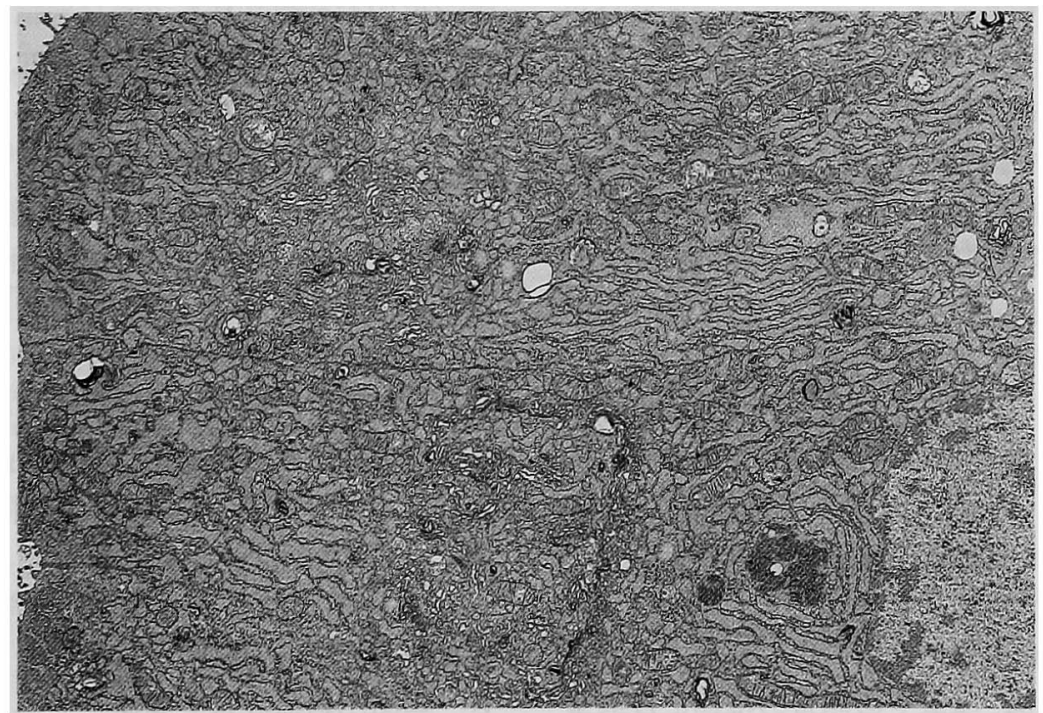

Fig. 14. Prostatic epithelial cells is SHR, 18 weeks old.

Rough endoplasmic reticulum is well-developed, but Golgi apparatus is undeveloped. Only a few secretory granules are seen. $\mathrm{U}-\mathrm{Pb}$ stain. $\times 5,500$. 


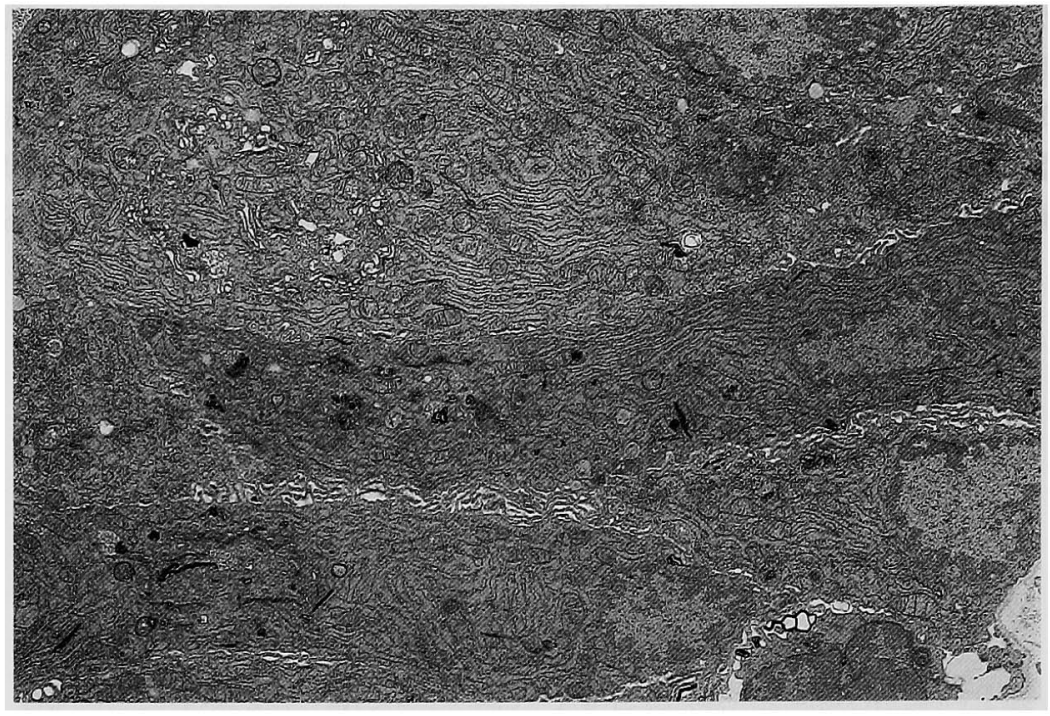

Fig. 15. Prostatic epithelial cells in SHR, 31 weeks old.

The intercellular gap is loose. Rough endoplasmic reticulum is well-developed, but it is not dilated Only a few secretory granules are recognized. Golgi apparatus is small in size and undeveloped $\mathrm{U}-\mathrm{Pb}$ stain. $\times 5,500$.

胞は腫大し，粗面小胞体は密に発達していたにも かかわらず，ゴルジ装置は小型で，濃縮空胞も少 なく，WKYに比較して分泌顆粒が明らかに少な かった(Fig. 13)。18 週齢では上皮細胞は細長い円 柱状を呈し，細胞質の大部分は拡張した粗面小胞 体で占められていた。しかし，核上部の粗面小胞 体の膜構造が不明瞭になり, 遊離りボゾームが増 加している細胞もあった。また，ゴルジ装置は小 型で, 濃縮空胞や分泌顆粒も少なかった(Fig. 14)。 31 週齢では, 上皮細胞はさらに細長くなり, 拡張 を示さない粗面小胞体と小型のゴルジ装置がみら れた他には, 分泌顆粒を含め, その他の細胞小器 官は 18 週齢とほほ同椂の形態を示していた (Fig. 15)。

\section{考 察}

前立腺の萎縮性変化は, 全身性栄責障害, 去 勢4,6,8,10,11 あるいは butyl benzyl phthalateの投与1 等によるアンドロゲン欠そによって起こることが 知られている。全身性栄養障害では, 精巣や胸腺 等の萎縮も伴われることが多い。しかし, 今回の SHR では一般状態, 体重や摂䬣量の推移には異常 はなく, 他の茞器にも萎縮性変化は認められな かった。また, 組織学的に前立腺上皮に萎縮性変
化はなかった。以上の所見から，SHRにおける前 立腺の変化は単なる萎縮性変化ではなく, 臓器特 異的なものとみなされる。

前立腺はアンドロゲン依存性であるので，その 分泌低下時には萎縮し, 組織学的には上皮細胞の 消失，間質の増加が招来されることは良く知られ た事実である。SHR の前立腺の変化は, アンドロ ゲン欠如で惹起されるような細胞自体の萎縮性変 化ではなかった。なお，SHRの血中テストステロ ン值は WKYのそれに比べむしろ高かった。した がって, SHR の前立腺の変化は去勢等によるアン ドロゲン欠乏による変化とは異質とみなされる。 Rodriguez-Padilka ら ${ }^{17}$ は,ラットにおいて血清 テストステロン值の上昇を伴う精囊と前立腺腹葉 の重量減少を認め, これはテストステロンに対す る副生殖腺の反応の低下によるものであろうと考 察している。前立腺の重量減少と血清テストステ ロン值の上昇は我々の SHRでも同様に認められ た。

SHR の前立腺の主な超微形態学的所見は分泌 顆粒の合成阻害を示唆するものであった。すなお ち, 粗面小胞体は良く発達しているにもかかわら ず，ゴルジ装置は小型で，濃縮空胞と分泌顆粒が 著しく少なかった。これは粗面小胞体からゴルジ 
装置への蛋白の移送障害を示す変化と考えられ た。このような蛋白の移送障害は, ATP レベルの 低下によるエチオニンの脂肪肝 ${ }^{2,5,12,13}$, ラットの 添腺の微小管障害による蛋白分泌抑制 ${ }^{3}$, ラットの 十二指腸における Tunicamysin による腸粘膜分 泌抑制 ${ }^{9}$ ，低温や ATP 産生抑制によるモルモット の膵臟外分泌腺のチモーゲン顆粒生成抑制 ${ }^{19}$, そ の他ラットの耳下腺の Brefeldin Aによる分泌物 生成抑制 20 等が知られている。これらの超微形態 学的特徵としては, 粗面小胞体腔の拡張, ゴルジ 装置の萎縮, 分泌顆粒の減少等が指摘されている。 今回の SHR の基本的な超微形態学的変化は, そ れらの変化と比較的類似していた。以上の結果加 ら, SHR の前立腺では, 先天的に何らかの原因で 粗面小胞体からゴルジ装置への蛋白の移送障害が 起こり，蛋白の合成ならびに分泌抑制が生じてい るものと推察される。

謝 辞 本研究を進めるにあたり，貴重な御意見を賜った 順天堂大学医学部第二病理白井俊一教授に深謝致します。 また，標本作製に協力を，そして貴重な御助言を頂いた当 社研究所員, 田中栄治, 佐野文子, 䅱岡正好, 神原由季, 伊 藤博子, 梁川美奈, 望月 淳, 高橋愛諸氏に感謝致します。

\section{文 献}

1. Agarwal, DK, Maronpot, JC, LAMB, IV, and Kluwe, WM : Adverse effects of butyl benzyl phthalate on the reproductive and hematopoietic systems of male rats. Toxicology 35: 189-206, 1985.

2. Baglio, CM and Farber, E: Ultrastrcutural consequences of biochemical lesions in the liver induced by ethionine. Fed Proc 24 : 556, 1965.

3. Busson-Mabillot, $\mathbf{S}$, Chambaut-Gu-Rin A-M, Ovtracht L, Muller, P, and Rossignol, B: Microtubules and protein secretion in rat lacrimal glands : Localization of short-term effects of colchicine on the secretory process. J Cell Biol 95 : 105-117, 1982.

4. Dahl, E and Kjaerheim, A: The ultrastructure of the accessory sex organs of the male rat. II. The post-castration involution of the ventral, lateral and the dorsal prostate. Z Zellforsch 144: 167-178, 1973.

5. Farber, E: Ethionine fatty liver (review). Adv Lipid Res 5: 119, 1967.

6. Harkin, JC: An electron microscopic study of the castration changes in the rat prostate. Endocrinology 60 : 185-199, 1957.

7. Hazama, F, Ooshima, A, Tanaka, T, Tomimoto, K, and Okamoto, $\mathrm{K}$ : Vascular lesions in the various substrains of spontaneously hypertensive rats and effect of chronic salt ingestion. Jpn Circ J 39: 7$22,1975$.

8. Helminen, HJ and Ericsson, JLE : Ultrastructural studies on prostatic involution in the rat. Changes in the secretory pathways. J Ultrastruct Res 40 : 152-166, 1972.

9. Kurihara, H, Ishikawa, K, and Fujita, H : Fine structural aspects of the effect of Tunicamycin on duodenal goblet cells of mice. Biomed Res 4 : 549$556,1983$.

10. Lee, $\mathrm{C}:$ Physiology of castration-induced regression in rat prostate. In: The Prostatic Cell : Structure and Function, part A : Morphologic, Secretory, and Biochemical Aspects. pp. 145-159. GP Murphy, AA Sandberg, and JP Karr Eds, Liss, New York, 1981.

11. Lee, $\mathrm{C}$ and Holland JM: Genital system. In : Monographs on Pathway of Laboratory Animals pp. 239-251. TC Jones, U Mohr, and RD Hunt Eds, Springer-Verlag, Berlin, 1987.

12. Mori, $\mathbf{M}$ : Ultrastructural changes of hepatocyte organelles induced by chemicals and their relation to fat accumulation in the liver. Acta Pathol Jpn 33 : 911-922, 1983.

13. 森 道夫, 小川勝洋 : 脂肪肝の病理と成因. 病理と 臨床 4 : 934-941, 1986.

14. 中田瑛浩：高血圧自然発症ラットの等丸動脈および 殬丸組織の高血圧変化：とくに結合織タンパク質を 中心として. 日泌会誌 75：927-933, 1984.

15. Nakada, T, Shigematsu, $H$, and Lovenberg, W: Testicular tissue injury of the stroke-prone spontaneously hypertensive rat associated with increased protein synthesis in the testicular arteries. Jpn J Fert Ster 27 : 148-155, 1982.

16. Okamoto, $\mathrm{K}$ and Aoki, $\mathrm{K}$ : Development of a strain of spontaneously hypertensive rats. Jpn Circ J 27 : 282, 1963.

17. Rodriguez-Padilla, M, Bellido, C, Pinilla, L, and Aguilar, E: Secretion of $\mathrm{LH}$ in spontaneously hypertensive rats. J Endocrinol 113: 255-260, 1987.

18. Suzuki, T, Yamamoto, $\mathbf{K}$, and Okamoto, $\mathrm{K}$ : Hypertensive vascular changes of testes in SHRSP. Jpn Heart J 21 : 598, 1980.

19. Tartakoff, AM: Temperature and energy dependence of secretory protein transport in the exocrine pancreas. EMBO J 5 : 1477-1482, 1986.

20. Yamashina, $\mathbf{S}$, Katsumata, $\mathbf{O}$, and Tamaki, $\mathbf{H}$ : Morphological effects of Brefeldin A on the intracellular transport of secretory materials in parotid acinar cells. Cell Struct Funct 15: 31-37, 1990. 